\title{
BIOEDUSCIENCE
}

ISSN: 2614-1558

\section{Status, Conservation Efforts and Rare Ornamental Plants in Kota Banda Aceh and Aceh Besar District}

\author{
Kiki Monita ${ }^{*}$, Ismul Huda ${ }^{2}$, Hasanuddin ${ }^{1}$, Fatilah Erni ${ }^{3}$ \\ ${ }^{1}$ Magister Pendidikan Biologi Universitas Syiah Kuala, Darussalam, Banda Aceh, Indonesia, 23111 \\ 2Pendidikan Biologi Universitas Syiah Kuala, Darussalam, Banda Aceh, Indonesia, 23111 \\ ${ }^{3}$ SMP Negeri 2 Banda Aceh, Kecamatan Kuta Alam Kota Banda Aceh, Indonesia, 23126 \\ *Email Koresponden: kikimonita.mpbio16@edu.unsyiah.ac.id
}

\section{ARTICLE INFO}

\section{Article history}

Received: 23 Oct 2020

Accepted: 20 Apr 2021

Published: 30 Apr 2021

\section{Keywords:}

Conservation

Plants

Rare

\section{A B S T R A C T}

Background: Ornamental plants have their charm and high economic value, but their population in nature is decreasing. This study aims to determine the types of rare ornamental plants, conservation status and conservation efforts. Methods: The methods used in this research are qualitative methods and exploratory surveys. The population in this study were all sellers/entrepreneurs of Decorative Garden Plants in Banda Aceh City and Aceh Besar District. The research period was eleven months, from September 2019 to August 2020. The data was collected through an exploratory survey, using the IUCN Red List application and semi-structural interviews. Interviews were conducted using a questionnaire, and descriptive statistical analysis was carried out for conservation efforts. The questionnaire contains questions about conservation efforts with available answer options to gather information related to research. Results: The results showed that the types of rare ornamental plants consist of 32 species, the conservation status is dominated by minimal concern (56\%) composed of 14 families. Conclusions: Rare ornamental plants are easily found in Kota Banda Aceh and Aceh Besar District. There is still a lack of conservation efforts such as protection, cultivation in preserving rare/endangered ornamental plants.

Status, Upaya Konservasi dan Jenis-jenis Tanaman Hias Langka di Kota Banda Aceh dan Kabupaten Aceh Besar

\section{A B S T R A K}

Background: Tanaman hias memiliki daya tarik tersendiri dan bernilai ekonomi tinggi, namun populasinya di alam semakin berkurang. Penelitian ini bertujuan untuk mengetahui jenis-jenis tanaman hias langka, status konservasi dan upaya konservasi. Metode yang digunakan dalam penelitian ini adalah metode kualitatif dan survei eksploratif. Populasi dalam penelitian ialah keseluruhan penjual/pengusaha Garden Tanaman Hias di Kota Banda Aceh dan Kabupaten Aceh Besar. Waktu penelitian selama sebelas bulan sejak September 2019- Agustus 2020. Pengumpulan data dilakukan melalui survei eksploratif, menggunakan redlist IUCN dan wawancara semistruktural. Wawancara dilakukan dengan menggunakan angket dan dilakukan analisis statistik deskriptif untuk upaya konservasi. Angket berisi soal-soal mengenai upaya konservasi dengan pilihan jawaban tersedia sehingga peneliti dapat mengumpulkan informasi terkait penelitian. Hasil: Hasil penelitian diperoleh jenis-jenis tanaman hias langka terdiri 32 spesies, status konservasi didominasi oleh kekhawatiran minimal (Least Concern) yaitu (56\%) yang terdiri 14 familia. Kesimpulan: Jenis tanaman hias langka mudah dijumpai di Kota Banda Aceh dan Kabupaten Aceh Besar dan saat ini masih kurangnya upaya konservasi yang dilakukan seperti perlindungan, budidaya dalam melestarikan tanaman hias yang langka/terancam punah.

(C2021 by authors. License Bioeduscience, UHAMKA, Jakarta. This article is open access distributed under the terms and conditions of a Creative Commons Attribution (CC-BY) license. 


\section{Introduction}

Indonesia is a country with a very high level of biodiversity. It can be seen in the different types of ecosystems and the genetic in each species. This high biodiversity is a natural wealth that can provide multipurpose benefits. It has vital strategic advantages, as the essential capital of national development and in the lungs of the world that would be needed in the future (Awanis et al., 2020; Suhartini, 2009).

There are currently people interested in the world of ornamental plants, from being interested in becoming lovers of plants and finally becoming hobbyists of ornamental plants. Many hobbyists are willing to spend significant amounts of money just because they fall in love with one potted plant (Besar et al., 2008). Besides that, many hobbyists are eager to spend their time just caring for their exclusive plant collections. This phenomenon has also allowed the public to be involved in the ornamental plant business for the domestic market and challenges to enter foreign markets. It is possible because Indonesia holds the title of one of the mega biodiversity countries (Putri et al., 2018). Widyastuti (2008) has reported that Indonesia has a diversity of orchid species of about 5,000 species scattered in Indonesia's forests. This situation is a precious potential for orchid development in Indonesia.

Ornamental plants are one of the horticultural commodities used as one of Indonesia's superior agricultural products. The amount of demand for ornamental plants changes at any time, depending on trends and consumer tastes in line with community income level (Aritonang et al., 2020).

One type of ornamental plant currently very popular in the community is Nepenthes. As an ornamental plant, this plant has its charm because of its uniqueness and high economic value. As an ornamental plant, this plant has its appeal because of its identity and high economic value. Nepenthes live scattered from coastal forests and in the highlands, but this plant becomes a rare and expensive item along with logging. Unfortunately, now the population in nature is decreasing (Akhriadi \& Hernawati., 2013).

Mumpuni et al. (2015) report that an increase in population impacts increasing the necessities of life. The exploration of various living resources continues. Biological resources include marine resources and forest resources, and resources such as ornamental plants. Exploration of natural resources makes a significant contribution to meeting community needs. Therefore, it is necessary to take action through a more in-depth study to determine the status, conservation efforts, and types of rare ornamental plant resources.

\section{Method}

This study uses a qualitative approach. This type of research is a survey that aims to collect data or information according to the facts of the research location. The research design was to collect data on rare ornamental plants, conserve rare ornamental plants, plant media, and the rarity of ornamental plants in Kota Banda Aceh and Aceh Besar District.

Furthermore, the distribution of interview questionnaires contained questions regarding the conservation efforts of rare ornamental plants found in garden sellers/entrepreneurs. After obtaining the data, data analysis on the types, conservation status, and conservation efforts of rare ornamental plants.

The research procedure carried in stages: determining research problems, making survey designs, developing survey instruments, determining samples, collecting data, checking data, coding data, data entry, processing and analyzing data, interpreting data, and making conclusions and recommendations.

\section{Data Collection and Analysis}

The data we're collecting by observing ornamental plants at garden sellers. Then, using the IUCN Red List application to determine the conservation status of rare ornamental plants at the research site.

Then, using the IUCN Red List application to determine the conservation status of rare ornamental plants at the research site. Each ornamental plant will be checked for the position through the IUCN web portal service https://www.iucnredlist.org/ by opening the web and entering the Red List program on the web.

Next, choose resources and categories and criteria, after which the name of the ornamental plant will be check for status written into the menu. Automatically, the species status is a list according to the IUCN category.

\section{Results}

\section{Types of Rare Ornamental Plants}

The types of rare ornamental plants found in garden sellers in Kota Banda Aceh and Aceh Besar District consist of 32 species (Table 1 ).

A rare ornamental plant that has a high frequency of presence is Ficus benjamina (Moraceae), commonly known as weeping fig (0.5172). The Apocynaceae is a type of tree and mainly developed as bonsai with a selling price of IDR $30,000,000$. Bonsai plants continue to sell for tens of millions of rupiah (Aryantha, 2005). In addition, there are three families with high economic value (prospective), namely Orchidaceae, Apocynaceae and Araceae. 
Tabel 1. Rare Ornamental Plants in Kota Banda Aceh and Aceh Besar District

\begin{tabular}{|c|c|c|c|}
\hline Family & Species & $\begin{array}{c}\text { Conservation } \\
\text { Status } \\
\end{array}$ & Endemicity \\
\hline Euphorbiaceae & Acalypha guineensis & $\mathrm{VU}$ & Guinea \\
\hline Euphorbiaceae & Euphorbia milii & DD & Timur Tengah \\
\hline Euphorbiaceae & Euphorbia tirucalli & LC & Afrika \\
\hline Euphorbiaceae & Codiaeum variegatum Bi & $\mathrm{LC}$ & India, Cina, Amerika \\
\hline Araceae & Anthurium eggersii & $\mathrm{CR}$ & Ekuador (subtropis/tropis) \\
\hline Araceae & Anthurium esmeraldense & VU & Ekuador (subtropis/tropis) \\
\hline Araceae & Xanthosoma eggersii & EN & Ekuador (subtropis/tropis) \\
\hline Araceae & Alocasia sanderiana & $\mathrm{CR}$ & Filipina \\
\hline Araliaceae & Schefflera actinopylla & LC & Australia, Papua, Jawa \\
\hline Arecaceae & Dypsis lutescens & NT & Madagaskar \\
\hline Arecaceae & Alocasia sinuata & CR & Filipina \\
\hline Arecaceae & Hyophorbe lagenicaulis & CR & Mauritius \\
\hline Apocynaceae & Adenium obesum & LC & Aden (Ibu kota Yaman) \\
\hline Apocynaceae & Tabernaemontana & $\mathrm{LC}$ & Indonesia \\
\hline Apocynaceae & Nerium oleander & $\mathrm{LC}$ & Afrika Utara, Mediterania Timur dan Asia Utara \\
\hline Asparagaceae & Agave schidigera & $\mathrm{LC}$ & California tenggara \\
\hline Asparagaceae & Cordyline fruticosa & LC & Asia Tenggara dan Oseania \\
\hline Colocasieae & Alocasia odora & $\mathrm{LC}$ & Asia Timur dan Tenggara \\
\hline Combretaceae & Terminalia mantaly & LC & Madagaskar \\
\hline Orchidaceae & Paphiopedilum papuanum & EN & Papua Nugini \\
\hline Orchidaceae & Grammatophyllum & Appendix II & Indo-Cina \\
\hline Orchidaceae & Phalaenopsis amabilis & Appendix II & Indonesia \\
\hline Podocarpaceae & Pocarpus macrophyllus & LC & Jepang dan Cina \\
\hline Moraceae & Ficus benjamina & LC & Asia, Malaysia, Australia \\
\hline Casuarinaceae & Casuarina equisetifolia & $\mathrm{LC}$ & Indo-Malaysia \\
\hline Casuarinaceae & Platycladus orientalis & NT & Asia timur dan Asia utara \\
\hline Rhamnaceae & Ziziphus mauritiana & $\mathrm{LC}$ & Asia Tengah \\
\hline Araucariaceae & Araucaria heterophylla & VU & New Caledonia \\
\hline Zamiaceae & Macrozamia communis & $\mathrm{LC}$ & Australia \\
\hline Asteraceae & Helianthus annuus & $\mathrm{LC}$ & Amerika \\
\hline Caesalpiniaceae & Tamarindus indica & $\mathrm{LC}$ & Afrika tropis \\
\hline Annonaceae & Cananga odorata & LC & India \\
\hline
\end{tabular}

\section{Conservation Status of Rare Ornamental Plants in Kota Banda Aceh and Aceh Besar District}

The conservation status of rare ornamental plants in Banda Aceh City and Aceh Besar District, several ornamental plants have been included in the IUCN red list.

Araceae found in several sellers, but Orchidaceae are the only two sellers who own these orchid plants, while Moraceae found in garden sellers and Euphorbiaceae.

The conservation status of rare ornamental plants dominated by Least Concern (56\%) consisting of 14 families, then followed by Critically endangered (12.50\%) composed of 1 family, Vulnerable (9.38\%) composed of 3 families, Endangered (6.25\%) consists of 2 families. Appendix II (6.25\%) consisted of 1 family, Near Threatened (6.25\%) consisted of 2 families, and Data Deficient (3.13\%) consisted of 1 family. Referring to the IUCN red list Database, 18 species (56.25\%) of rare ornamental plants were found to be Least Concern status or at low risk of extinction (Figure 1).

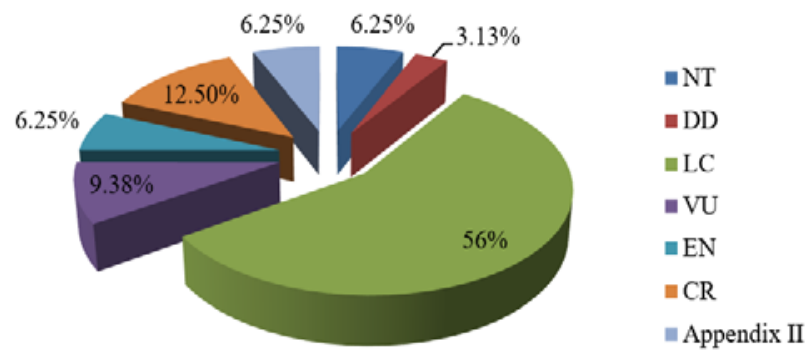

Figure 1. Percentage of Rare Ornamental Plants Conservation Status in Kota Banda Aceh and Aceh Besar District 


\section{Conservation Efforts of Rare Ornamental Plants in Kota Banda Aceh and Aceh Besar District}

Conservation efforts carried out on sellers of rare ornamental plant gardens in Banda Aceh, and Aceh Besar pays attention to planting media such as manure. In addition, the selection of seeds according to quality.

\section{Discussions}

Overall, of the 32 species of rare ornamental plants in Kota Banda Aceh and Aceh Besar District, several families with high economic value (prospective), including the Orchidaceae, Apocynaceae and Araceae families. The three families are worth hundreds or even millions of rupiah to get it and become the leading commodity of floriculture (Widyastuti, 2018). While the Orchidaceae family has an attraction, namely the various parts of the flower, the orchid plants have produced many beautiful new hybrids. Therefore, the trend of orchid plants is still a significant enthusiast for mothers (Diatmika et al., 2016).

Those interested in rare ornamental plants are a hobby they have because most supports consumers or lovers of ornamental plants to maintain these plants are the rarity status of these types of plants. Forest ornamental plants with high scarcity status will be increasingly sought after, popular and have a high selling value (Hendaryono, 2000).

Aglaonema and Acalypha ornamental plants dominant in sellers are not classified as endangered ornamental plants because they not included in the IUCN Red List. However, it is different from orchids which are endangered ornamental plants. According to (Sastrapradja et al., 1976), black orchids are a type of orchid that is in great demand by the public, so that their existence threatened due to the excessive exploitation of orchids from nature. Even if this happens continuously, the black orchid will experience extinction.

Furthermore, spraying pests is also essential in conservation efforts to control pests and diseases intensively. If the plants experience this disturbance, it will reduce the yield much (Widyastuti, 2018). The amount of losses due to plant disturbances depends very much on the weight and extent of the attack. Plant diseases can be preventive or curative.

Besides that, giving husks is also very much needed in the preservation of rare ornamental plants. According to (Budiarto et al., 2006), adding charcoal and husks to the growing medium will improve soil properties (porosity, aeration) and help bind nutrients. Meanwhile, (Zulkaidhah et al., 2018) mention that coconut coir (cocopeat) also needed for the preservation of rare ornamental plants, which helps in water holding capacity.

\section{Conclusions}

The types of rare ornamental plants found in ornamental plant sellers in Kota Banda Aceh and Aceh Besar District consist of 32 species. Conservation status of rare ornamental plants dominated by Least Concern (56\%), Critically endangered (12.50\%), Vulnerable (9.38\%), Endangered (6.25\%). Appendix II (6.25\%), Near Threatened (6.25\%), and Data Deficient (3.13\%). Referring to the IUCN red list Database, 18 species (56.25\%). Conservation efforts carried out on sellers attention to planting media such as manure and selection of seeds according to quality.

\section{Declaration statement}

The authors reported no potential conflict of interest.

\section{References}

Akhriadi, P., \& Hernawati. (2013). A Field Guide to the Nepenthes of Sumatera. Pilingo Movement.

Aritonang, J., Nugraeny, L., Sumiatik, \& Siregar, R. N. (2020). Peningkatan Pemahaman Kesehatan pada Ibu hamil dalam Upaya Pencegahan COVID-19. Jurnal SOLMA, $9(2)$,

261-269. https://doi.org/10.22236/solma.v9i2.5522

Aryantha, I. N. P. (2005). Strategi Risert dan Pengembangan dalam Pengelolaan Potensi Biodiversitas.

Awanis, H., Huda, I., \& Sarong, M. A. (2020). Conservation status of shark fish in the Aceh province coastal area. IEDP Sciences., 1012.

Besar, B., Bioteknologi, P., Pemuliaan, D., Hutan, T., Pamungkas, T., \& Balai Besar, Y. (2008). Peranan Taman Hutan Raya Dalam Konservasi Sumberdaya Genetik : Peluang Dan Tantangannya (Vol. 6, Issue 2).

Budiarto, K., Sulyo, Y., Maaswinkel, R., Wuryaningsih, S. Hilman, Y., \& Effendie, K. (2006). Budidaya Krisan Bunga Potong. Puslitbang Hortikultura.

Diatmika, N., Setiawina, D., \& Djayastra, K. (2016). Analisis Faktor-faktor Yang Mempengaruhi Pendapatan Petani Anggrek Di Kota Denpasar. E-Jurnal Ekonomi Dan Bisnis Universitas Udayana 5.

Hendaryono. (2000). Pembibitan Anggrek dalam Botol. Kanisius.

Mumpuni, K. E., Susilo, H., \& Rohman, F. (2015). The Role of Society Toward Concervation. Seminar Nasional XII Pendidikan Biologi FKIP UNS 2015, 779-782.

Putri, R. K., Nurmalina, R., \& Burhanuddin, B. (2018). Analisis Efisiensi Dan Faktor Yang Memengaruhi Pilihan Saluran Pemasaran. Mix: Jurnal Ilmiah Manajemen, $8(1), \quad 109$. https://doi.org/10.22441/mix.2018.v8i1.007

Sastrapradja, S., Nasution, R. E., Irawati, Soerojo, L., Imelda, M., Idris, S., \& Sutomo Soerohaldoko, W. R. (1976). Anggrek Indonesia. Lembaga Biologi Nasional LIPI.

Suhartini. (2009). Prosiding Seminar Nasional Penelitian, 
Pendidikan dan Penerapan MIPA, Fakultas MIPA.

Widyastuti, E. (2008). PERAN IPTEKS DALAM AGRIBISNIS TANAMAN HIAS. Agritech: Jurnal Fakultas Pertanian Universitas Muhammadiyah Purwokerto, 10(2). https://doi.org/10.30595/AGRITECH.V10I2.965

Widyastuti, T. (2018). Teknologi Budidaya Tanaman Hias Agribisnis. CV Mine.

Zulkaidhah, U., Hapid, A., \& Toknok, B. (2018). Upaya Konservasi Tanaman Hias Anggrek Melalui Perbanyakan Secara Vegetatif Dan Kultur Jaringan. In Jurnal Pengabdian Pada Masyarakat (Vol. 6, Issue 10). http://jurnal.untad.ac.id/jurnal/index.php/jppm/arti cle/view/10683 